\title{
Invasive species of the order Hemiptera in agrocenoses of Southern Russia
}

\author{
Leonid Esipenko ${ }^{1, *}$, Alexander Podvarko ${ }^{1}$ \\ ${ }^{1}$ Federal state budgetary scientific institution "All -Russian research institute biological protection of \\ plants", 39, 350039, Krasnodar, Russia
}

\begin{abstract}
The distribution of invasive species is associated with a change in the distribution boundaries of individual taxa and non-taxonomic groups, with its development of new biotopes, change in the structure and functioning of individual ecosystems. Invasive species in Russia is a wellknown phenomenon. Over the past 50 years, more than 10 herbivorous species have been discovered which are classified as quarantine species. In the near future, the appearance of new aggressive species such as Diabrotica virgifera virgifera Le Conte - western corn bug, Popillia japonica Newm - Japanese beetle and others is expected.
\end{abstract}

\section{Introduction}

In the new climatic conditions, the adventive species in acclimatization phase undergoes microevolutionary changes in the genetic and phenetic structure. During this period, the introducenter rapidly multiplies due to the redistribution of energy resources [1,2] and dominates in biogeocenoses due to the lack of constant components of consortia in cenoses that hinder its development in the native range. As a result, introduced species become aggressive, create a dangerous situation for native biocenosis or agrobiocenosis [3]. In integration phase, the adventive species is included in the trophic chains of the ecosystem, forming a complete food chain and the introducer becomes a constant component of the biocenosis consortium [4,5]. In this regard, it is very important to distinguish invasive species from indigenous representatives of fauna, which is very poorly studied.

Advent of adventive species is unpredictable catastrophe. To ensure international joint and effective actions aimed at preventing the introduction and spread of dangerous organisms, the Scientific Committee on Problems of the Environment is organized. Already in 1980, the first information about the appearance of invasive species: Ecology of biological invasions of North America and Hawaii [6] and Biological invasions: a global perspective. There was established the Intergovernmental organization EPPO (European and Mediterranean Plant Protection Organization), including almost all countries in Europe and the Mediterranean region (51 countries). EPPO aims to develop an international strategy to prevent the spread of pests in biogeocenoses and agrobiocenoses. With the formation of the European Union, emergencies related to invasive species have become relevant. In this regard, in 2015, the decision of the European Union in the field of

\footnotetext{
${ }^{*}$ Corresponding author: esipenkol@yandex.ru
} 
biological invasions began to take effect. All partners of the Convention on Biological Diversity have committed themselves to take administrative measures to reduce the negative impact of invasive species on indigenous ecosystems.

In this regard, the goal of our work is to conduct a zoogeographic analysis of the semirigid winged invasive species in agrocenoses of the South of Russia and to give its brief description.

\section{Material and methods}

The studies were carried out in 2011-2017. in the Krasnodar Territory. During the research, generally accepted research methods in entomology and plant protection were used.

The species composition of semi-winged and agrocenoses was studied throughout the growing season from April to October using the route surveys method; when catching insects, the entomological net and the method of mechanical capture of individuals in test tubes were used. The systematic belonging of insects was carried out using well-known determinants [7] and with the involvement of an electronic resource.

\section{Results and discussion}

Over the past decade, several new invasive species have been recorded for the fauna of the Krasnodar Region. The harmfulness of the Hormoptera squad especially increases, especially (Hemiptera) or proboscis (Rhynchota). Cicadas were found in vineyards (Cicadellidae): humpbacks (Membracidae) - buffalo (Ceresa bubalus Fab.), Japanese grape cicadas (Arboridia kakogawana Mats.) and citrus cicadas or white (Metcalfa pruinosa Say) $[8,9]$ These species cause serious damage not only in the vineyards, but also in other crops.

Of particular danger is the cicadas M. pruinosa Say. from North America to XX penetrated the Neotropic region, and at the beginning of the XXI century it was brought to the Palearctic region (Italy, France, Spain, Great Britain, Czech Republic, Croatia, Slovenia, Austria, Greece, Switzerland, etc.), as well as to Germany and Romania. In Russia, a white circadian was first noted by V.M. Gnezdilov and E.S. Sugonyaev in the village Lazarevskoye (Sochi region) in 2009 [10] (fugure 1)

The penetration of the species in the Krasnodar Region occurred due to sea transport through the Black Sea ports. The advance of the insider to the north of the region is connected with a wide network of land roads going along the edge.

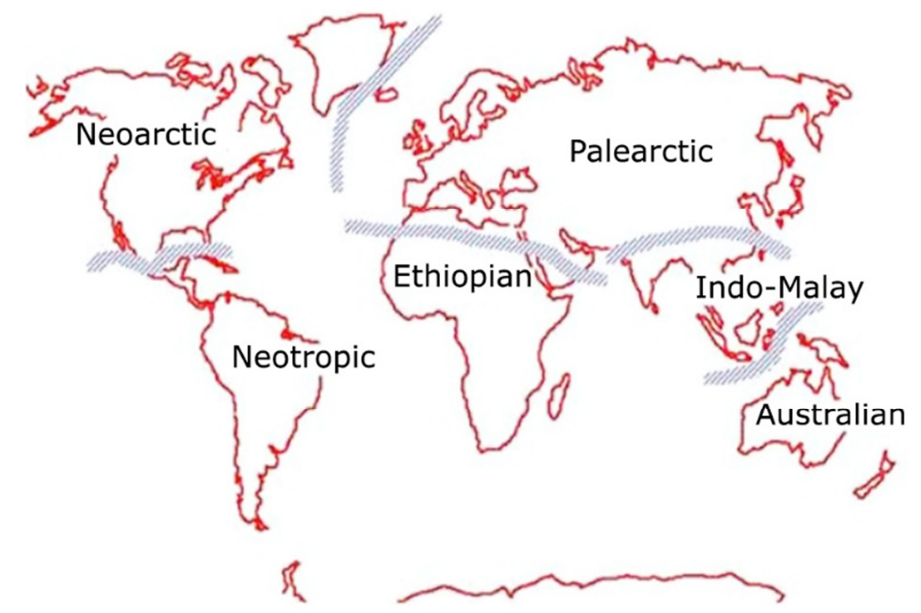

Fig. 1. Propagation of white cicadas. 
In Europe, M. pruinosa is registered in 110 plant species of 49 botanical families [11]. From crops damages rice, barley, corn, soy, wheat, sorghum, carrots, tomatoes, potatoes. In the Krasnodar region M. pruinosa found on apple, pear, plum, peach, grape, wild strawberry, raspberry, blackberry, common ash, maple, roses, bird cherry.

Nymphs are found on blackberry, raspberry, apple, pear, peach, cherry plum, hazelnuts, walnuts, and numerous ornamental wood and shrub plants. Food usually does not lead to deformation of leaves and shoots, but products lose its presentation due to contamination with sticky secretions. These secretions create a favorable environment for the development of soot fungi, which interfere with normal photosynthesis. Cicadas may also be potential carriers of viral diseases.

The economic threshold for the harmfulness of the white cicadas has not been fully determined in Russia, and is regarded as insignificant, but it is obvious that the harmfulness in new habitats is much higher than in the homeland. So, in Italy, crop losses in soybean culture reach $40 \%$ [12]. In Greece, to control the pest were forced to use chemicals [13]. To combat the cicadas, mechanical pruning of shoots is recommended in places where eggs are likely to be laid in the autumn and winter, as well as the release of an entomophage Neodryinus typhlocybae (Ashmead), which is of American origin and was introduced to Italy to suppress $M$. pruinosa by Professor Girolami Vincenzo, [14]. Local pruning of greenery populated by the cicadas in Krasnodar in 2010 made it possible to reduce its numbers in 2011.

Bedbugs of the Pentatomidae family were identified in the southern area of Krasnodar region on agricultural and ornamental crops. According to the type of food, it belongs to polyphages and in a short time became serious phytosanitary objects. Some are included in the Unified List of Quarantine Objects, which is approved by the Eurasian Economic Commission. This is a green vegetable bug Nezara viridula (Linnaeus, 1758) and brownmarble bug Halyomorpha halys Stål, 1855.

$N$. viridula is a cosmopolitan species living in the non-arctic and neotropic regions [15], from where it spread around the world due to its good ability to move through the air (figure 2).

First information about $N$. viridula were given by V.V. Neimorovets (2010) for the Krasnodar region. In his work, the author noted that the green vegetable bug was originally distributed along the Black Sea coast and in some mountainous regions. At present time the bug has safely "overcome" the mountains and settled everywhere on the Zakuban Plain and the Prikuban Lowland of the Krasnodar region, and began to damage many agricultural crops cultivated in the region, such as soybeans and tomatoes.



Fig. 2. Spread of a green vegetable bug. 
Brown-marble bug (Halyomorpha halys Stål) registered in the Russian Federation in 2014 on the Black Sea coast. Previously, it was noted in the Republic of Abkhazia, where it became a serious pest of citrus and nut crops. Currently, it is found in the central zone of the Krasnodar region. Danger of H. halys in the territory of the region is obvious. In this regard, special workshops were held in the Department of Plant Growing, Mechanization, Chemicalization and Plant Protection of the Ministry of Agriculture of Russia (protocol № 19/580 by February, 7, 2018), where a program was developed to limit the distribution of brown-marble bugs in southern Russia.

Another no less dangerous is the representative of the Tingidae species, which was first registered in the 60s of the 20th century in Europe; North American species Corythucha ciliata (Say, 1832) - Padded Lace-up in Padua (Italy). It has spread to most of southern and central Europe, and this is due, according to many authors, to anthropogenic factors [16]. The native range of the species includes the non-Arctic zone (northern, southern and eastern parts of the United States and covers the provinces of Ontario and Quebec in Canada) [17]. At the end of the 20th century, the plane-tree corituha began to spread actively in the lowland and foothill parts of the Northwest Caucasus (figure 3).

Imago and platan lace larvae are mainly fed by plant juices on the leaves of trees, mainly of the western platan Platanus occidentalis L., maple leaf, or hybrid P. x acerifolia (P.hibrida). Often there observed its nutrition on other types of trees. Drake and Rukhoff plane-lace was marked on ash Fraxinus sp., and oak Quercus laurifolia Michx [18]. In this case, the process of photosynthesis and respiration is disturbed and the leaf mass of the plant falls and the decorativeness of park zone is lost.

Studies by foreign authors have shown that in addition to the damage done, lace makers can carry hyphae and spores of fungi, some are pathogenic species, for example, Ceratocystis fimbriata f. sp. platani (Cfp) and Apiognomonia veneta (Sacc. \& Speg.) Höhn, leading to the death of trees [19].

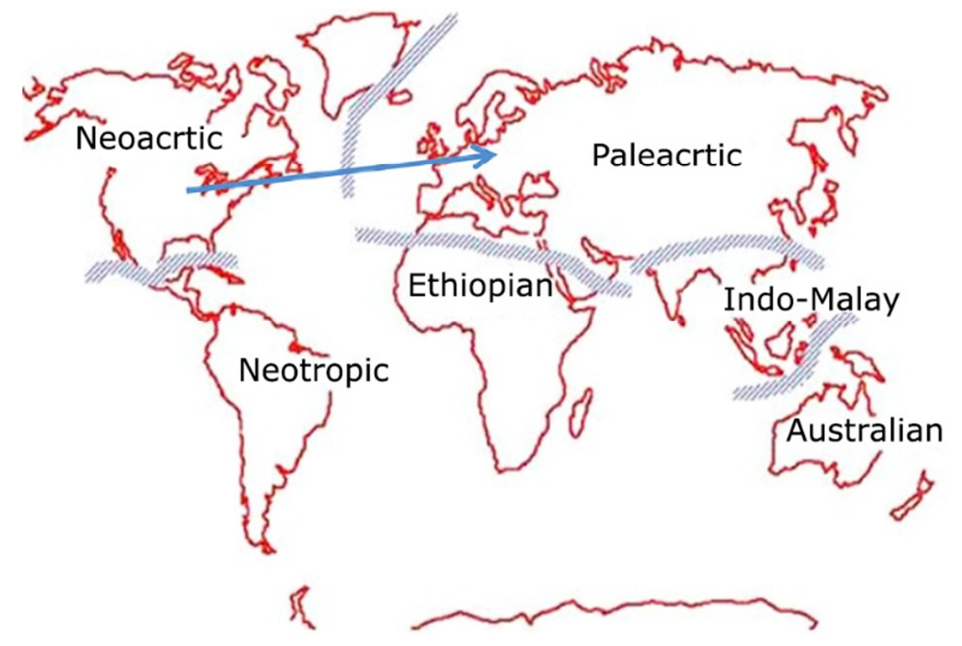

Fig. 3. Distribution of platan lace.

In Russia, the first finds C. ciliate were discovered in 2001 in Krasnodar region and Republic of Adygea [31]. The authors found the first laces in 1998 in the Slavyansk area of Krasnodar region, and in 2002 in Abkhazia. 


\section{Conclusions}

The spatiotemporal nature of biological invasions and the uncertainty regarding effective control indicate a lack of research in the field of species biology and economic consequences, and this is directly related to Russia's biosafety issues.

In this regard, it becomes necessary to model the forecast of risks of invasive species in order to develop programs for managing populations of invasive species in order to optimize the phytosanitary state of anthropogenic ecosystems.

\section{Acknowledgement}

The research was carried out in accordance with the state task No 075-00376-19-00 of Ministry of Science and Higher Education of the Russian Federation as part of a study on topic No 0686-2019- 0010 and partly with the support of the FSBI "RFBR" and the Administration of the Krasnodar region as part of the projects №16-44-230780 and №1944-230004

\section{References}

1. B. Blossey, R. Notzold, Journal of Ecology 83(5), 887-889 (1995)

2. M. Williamson, B. Griffiths, Biological Invasions (Springer Science \& Business Media, 1996)

3. G.H. Rodda, C.S. Jarnevich, R.N. Reed, Biol Invasions 11, 241-252 (2009)

4. D.M. Richardson, N. Allsopp, C.M. D’Antonio, S.J. Milton, M. Rejmánek, Biological Reviews 75, 65-93 (2000)

5. H.A. Mooney, S.P. Hamburg, J.A. Drake, In Ecology of Biological Invasions of North America and Hawaii (Springer, New York, 1988)

6. C.J. Drake, F.A. Ruhoff, Lacebugs of the world: A catalog (Hemiptera: Tingitidae) (Smithsonian Institution, Washington, D.C., 1965)

7. V.M. Gnezdilov, T.S. Sugonyaev, Zoosystematica Rossica 18(2), 260-261 (2009)

8. I.V. Balakhnina, Entomologicheskoe Obozrenie 93(3), 532 - 538 (2014)

9. V.M. Gnezdilov, REDIA XCI, 51 - 54 (2008)

10. C. Preda, M. Skolka, Ecologia Balkanica 3(1), 79-87 (2011)

11. M. Ciampolini, et al., L'Informatore Agrario 43(15), 101-103 (1987)

12. C. Preda, M. Skolka, Ecologia alkanica 3(1), 79-87 (2011)

13. F. Frilli, A. Villani, P. Zandigiacomo, Entomologica 35, 27-38 (2001)

14. J.W. Todd, Annu. Rev. Entomol. 34, 273-292 (1989)

15. R. Pralavorio d' Aguilar, J.M. Rabasse, R. Mouton, Bulletin de la Societe Entomologique de France 82, 1-2 (1977)

16. A. Servadei, Bull. Soc. Ent. Ital. 96, 94-96 (1966)

17. C.J. Drake, F.A. Ruhoff, United States National Museum Bulletin 243, 634 (1965)

18. M. Maceljski, Bull. OEPP 16(4), 621-624 (1986)

19. K. Voigt, Zoosystematica Rossica 1(10), 76 (2001) 